\title{
개발재원에 관한 고위급대화 총회 개최 결과 ( 2007.10.23-24)
}

원조의 양적 증대를 위한 몬테레이 컨센서스가 채택된 이후, 개발재원이 증대 되었으나, 최빈개도국이 그 혜택을 받지 못하는 배분의 형평성 문제가 최근 대두되고 있다. 이에 UN 총회 의장, 사무총장 및 주요 국제기구와 원조공여국 대표들이 모여 개발재원의 균등분배, 국제개발금융기구 개혁과 공여국수원국과의 파트너십에 대해 논의하였고, 동 회의 결과는 향후 우리 원조 방향에 대해 시사하는 바가 크다. [ 정리 : 정책연구실 ]

I. 총회개요

- 명칭 : 개발재원에 관한 고위급 대화 (HighLevel Dialogue on Financing for Development) 총회

- 주제 : MDG 달성을 위한 몬테레이 컨센서스

(Monterrey Consensus)의 이행 현황

및 향후 조치 방향 검토

- 참가자 : Srgjan Kerim 유엔 총회 의장, 반기문 유엔 사무총장, Danny M. Leipziger 세계은행 부총재 등 개

\section{II. 상세 내용}

발관련 주요 국제기구 간부 및 한 국, 영국(국제개발부 장관) 등 92 개 국 대표

\section{1. 주요 내용}

- 몬테레이 컨센서스가 채택된 이후 세계 ODA 규모가 확대되고, 공여국의 숫자도 증가하고 있 으나, 사하라 이남의 아프리카 국가 등 일부 최 빈 국가들이 ODA의 혜택으로부터 소외(aid 
orphan)됨에 따라 원조배분의 형평성 문제가 제기되고 있는 등 전반적인 추진현황의 점검과 보완이 필요

- 개도국들이 개발에 필요한 재원을 확보하려면 거시경제 및 금융시장을 안정시킴으로써 해외 자본이 유치될 수 있는 여건이 조성되어야 하며 선진공여국들은 이러한 개도국들의 노력을 지 원해야 함

- 중장기 개발재원 확보 수단으로 무역확대를 통 한 개도국의 능력제고 (Aid for Trade)가 필요 하며, 농업보조금 철폐 및 반덤핑 등 규제조치 완화를 통해 개도국들에게 유리한 국제무역 환 경을 조성할 필요가 있음

- 국제개발 금융기구 및 통화 기구의 개혁을 통해 개도국들의 입장이 국제금융체제(IFI)에서 보다 중요하게 반영될 수 있도록 노력해야 함

\section{2. 주요 발언 요지}

\section{- Kerim 유엔 총회 의장(개회사)}

- 2002년 회의에서 설정된 개발재원 관련 목 표들이 일부 성공적으로 행되고 있기는 하 지만, 현재의 진행속도로는 대부분의 목표 들을 달성하기가 어려운 상황인바, MDGs 목표달성을 위해 획기적인 조치를 강구할 필요가 있음
- 몬테레이 컨센서스의 이행을 저해하는 요소 로는 개발재원의 지역간 불균등한 분배, 자유 롭고 형평한 다자무역체제를 방해하는 새로 운 형태의 보호무역주의 등장, 국제개발금융 기구 개혁의 둔화 등을 들 수 있으며, 2008년 도하에서 개최되는 몬테레이 컨센서스 이행 상황 점검 회의를 계기로 이러한 문제점이 해 결되기를 희망함

- MDGs와 더불어 몬테레이 컨센서스는 UN과 여타 국제기구, 시민단체, 민간 부문 등 다양 한 계층의 개발에 대한 열정과 역량을 결집 시키는 역할을 하고 있음

\section{- 반기문 UN 사무총장}

- 2002년에 개최된 UN 개발재원회의는 ODA 관련 이슈들을 새롭게 조명함으로써 국제개 발협력의 전환점이 되었으며, 동 회의를 계기 로 선진공여국과 개도국간 협력관계의 중요 성이 부각되었음

- 2002년 이후 세계 개발원조가 질적, 양적으 로 발전한 것은 사실이나, 사하라 이남 아프 리카의 경우에서 볼 수 있듯이 개발원조의 혜택이 고르게 분배되지 못하는 문제가 노 정됨

- 개발원조의 효과를 제고하기 위해서는 ODA 의 양적 증대뿐 아니라, 원조 효과 분석, 부채 탕감 노력의 증대, 거시경제의 신중한 운영 및 금융시장의 안정 등 다양한 조치의 병행이 필요함 
- 특히, 저소득 국가로는 국제자본이 유입되지 않는 경향이 있으므로 지속가능한 경제개발 을 위해서는 이들 국가의 거시경제를 안정시 키고 정치적 불안을 제거함으로써 해외자본 유치에 유리한 여건을 조성해야 함

- 범세계적 평화와 번영을 위해서는 질병, 빈곤 등 비인도적 상황을 조속히 종식시켜야 하며, 이를 위해서는 개발협력을 통한 개도국 · 공 여국간 파트너십 제고가 필요함
역에서도 일부 국가만 개발의 혜택을 받는 등 지역별로 형평한 개발이 이뤼지지 못 하고 있 는 실정이므로 개발혜택의 형평한 분배를 위 해 노력해야 함

- 또한 개발원조의 효과를 제고하기 위해서는 수원국 거시경제의 안정을 통해 원조 수용능 력을 향상시키고 부채구조를 개선하며, 다양 한 개발재원 확보방안을 마련하는 등 다각적 인 노력이 필요함

\section{- Leipziger 세계은행 부총재}

- 2002년 회의 이후 5년이 지난 현 시점에서 지금까지의 이행상황을 점검해 보면, 공여국 의 부채탕감 노력 증대 및 수원국의 원조 관 리 능력 제고 등의 측면에서 긍정적인 효과를 거둔 것이 사실임

- ODA의 규모도 증가하였으나, 2004년 이후 증 가분의 대부분은 부채탕감(debt cancelation) 에 의해 이루어졌는바, $\mathrm{OECD} \mathrm{DAC} \mathrm{회원국들}$ 의 2006 년 $\mathrm{ODA}$ 규모는 실제로 $5.3 \%$ 감소 했음

- 개발원조의 효과를 제고하려면 국제무역시스 템을 개발에 유리한 방향으로 개선할 필요가 있으며, 이를 위해서는 도하 라운드의 성공적 타결이 중요

\section{- IMF}

- 저개발 지역의 금년도 경제성장률은 대체로 긍정적이라고 할 수 있으나 서부 아프리카 지

\section{- WTO}

- 중장기 개발재원 확보에 중요한 역할을 하는 무역의 경우, 농업보조금, 반덤핑조치 등 개 도국에 불리한 무역규제 장치를 완화하는 것 이 필요

- MDGs 목표 달성 실패의 대가를 감안, 지도 자들이 정치적 결단을 통해 과감한 개발 전 략을 추진해야 함

\section{- UNCTAD}

- 2006년 한 해 동안 개도국에 유입된 FDI는 3,790 억 달러로 사상 최고치를 기록했으나, 개도국으로 유입된 전체 자본의 $70 \%$ 가 12 개 국가에 집중되었으며 최빈개도국에 유입된 비율은 $2.5 \%$ 에 불과했음

- 개도국들이 세계 자본시장에 접근할 수 있도 록 국제금융구조를 개편할 필요가 있음

- 또한 개도국의 외환보유고 증가는 외환위기 에 대해 완충작용을 한다는 긍정적인 측면이 
있으나 국제 금융시장의 불안정성을 전제로 시행하는 사전예방조치라는 측면에서 부정적 인 측면도 있음을 부인하기 어려움
이행할 것이며, 개발과 환경 문제가 불가분의 관계에 있다는 점을 인식하고 두 가지 문제 모두를 해결하기 위해 노력해 나갈 것임

\section{- Group of 77 및 중국}

- G77 및 중국의 관점에서 세계경제의 전망은 그리 낙관적이지 못 함

- 일부 개도국이 역동적인 경제성장을 달성하 고 부채구조를 개선하는 등 긍정적인 결과를 도출하고 있으나 대부분의 개도국들은 빈곤 의 악순환에서 헤어나지 못하고 있으며, 개도 국 전체의 부채액도 증가하고 있음

- 이러한 상황을 타개하기 위해서는 선진공여 국들의 ODA 규모 증액, UN 등 개발 및 금융 관련 국제기구들의 개도국 민자 유치 지원, 부채탕감 프로그램의 강화 등 다각적인 노력 이 필요함

\section{- EU}

- EU는 몬테레이 컨센서스의 성실한 이행을 위해 2015년까지 회원국의 ODA 비율을 GNI 대비 $0.7 \%$ 로 높이는 것 외에도 중간 목표로 2006년까지 전체평균 0.39\%, 2010년까지 $0.56 \%$ 를 제시하였으며, 2006년 목표인 $0.39 \%$ 는 이미 달성했음. $\mathrm{EU}$ 는 현재 전세계 $\mathrm{ODA}$ 의 $57 \%$ 를 부담하고 있음

\section{- 독일}

- 독일정부는 EU의 ODA 달성 목표를 성실히

\section{- 영국}

- 영국의 ODA 규모는 2002년 이후 $30 \%$ 증가 했으며, 2013년까지 GNI 대비 0.7\% 수준을 달성할 계획임

- 2008년 회의를 계기로 ODA 확대 계획이 정 상 궤도에 오를 것으로 기대되는바, $\mathrm{ODA}$ 효 과를 제고하기 위해서는 예측가능한 장기 원 조 계획 수립 및 공여자간의 협력체제 구축이 필요하며 정치적 의지가 수반되어야 함

\section{- 한국}

- 현재 세계는 금융시장이 안정되고 물가가 낮 은 수준을 유지함에 따라 개발 목표 달성에 유리한 여건이 조성되고 있음

- 국제사회는 ODA 규모를 2000년 530억불에 서 지난 해 1 천억 불로 증액 시키는 등 빈곤 과 질병 퇴치를 위해 노력하고 있으며, 이러 한 노력이 여러 분야에서 긍정적인 결과로 나타나고 있으나 개발의 혜택이 형평하게 분 배되지 못하여 최빈개도국의 극빈을 경감시 키는 데에는 그리 성공적이지 못했던 것으로 드러남

- 하지만 공여국의 숫자가 증가하고 있다는 것 은 희망적인 징후라고 할 수 있음. 한국과 같 은 신흥공여국의 경우, 자신의 개발경험을 수 
원국에 전수함으로써 수직적 구조의 국제원 조체제를 보다 더 유연하게 개선하는 데 기여 할 것으로 기대됨

- 한국은 2010년에 OECD DAC에 가입할 예정 이며, 몬테레이 컨센서스를 이행하고 국제사 회에 대한 기여를 확대하기 위해 ODA 규모 를 2015년까지 32억불 수준으로 확대할 계 획임

- 또한, 항공권 연대기금을 도입하고 "개발재원 연대기금 지도자 그룹” 제 3 차 총회를 주최하 는 등 국제사회의 혁신적 개발재원 발굴 노력 에도 적극 동참하고 있음

- 천연자원이 부족한 한국의 경우, 수출산업 육 성을 통한 외환 축적과 인적자본 육성 그리고 장기 개발전략의 수립 - 이행을 통해 경제 개 발에 성공할 수 있었으며, 이러한 한국의 발 전 경험은 여타 개도국에게 좋은 선례가 될 것으로 판단됨

\section{- 네덜란드}

- 최근의 국제개발협력 현황을 살펴보면, 2006 년도 전세계 $\mathrm{ODA}$ 규모 감소, 개발관련 무역 협상의 정체, 부채 탕감 제도의 불완전성 등 많은 문제점들이 노정되고 있음

- 이러한 문제점들을 해결하기 위해서는 ODA 규모를 확대해야 하며, 네덜란드는 지난 수 십 년 동안 $\mathrm{GNI}$ 대비 $0.8 \%$ 의 $\mathrm{ODA}$ 를 유지해 왔음

- 또한 최빈국들의 환경문제 대응 능력 향상을
위해 7억 유로를 추가로 공여할 계획임

- 무역의 경우, 최빈국들이 세계무역체제에 진 입할 수 있도록 지원할 필요가 있음

\section{- 일본}

- MDG 설정 이후 동아시아 및 남아시아에서 극빈 인구가 감소추세를 보이고 있으며, 유아 사망이 천만명 미만으로 줄어들었음

- 하지만 사하라 이남 아프리카 국가들의 개발 은 미진한 상태이며, 현재의 추세대로라면 이 들 국가들은 2015년까지 MDG 목표들 중 단 하나도 달성하기 어려운 상황임

- 일본은 아프리카 개발 원조를 최우선 과제로 생각하고 있으며, 내년 5월에 제4차 '아프리 카 개발에 관한 동경 국제회의(Tokyo International Conference on African Development)' 를 개최할 예정임

- 일본은 2005 2009년간 ODA 규모 100억불 증액을 위해 노력하고 있으며 2007년 말까 지 아프리카에 대한 ODA 규모를 2 배 확대할 계획임

\section{- 인도}

- 몬테레이 컨센서스의 이행실적이 저조한 실 정임. 특히, 국제 금융 및 통화 기구의 개혁을 통해 개도국들의 참여를 활성화시키고 의사 를 제대로 반영할 수 있는 체제를 갖추는 것 이 시급함

- 또한 민간 자본의 유치를 통해서는 사회 기반 
시설 확충이 어려우므로 개도국들의 개발을 위해서는 선진공여국들의 ODA 확대 노력이 필수적임에도 불구하고 최근 $\mathrm{ODA}$ 규모가 감 소 추세를 보이고 있음

- 이러한 추세가 지속된다면 2010년까지 선진 공여국들의 ODA는 GNI 대비 $0.36 \%$ 정도에 불과할 것으로 전망됨

- 또한 개발에 우선순위를 두고 도하 라운드를 진행시켜 개도국들에게 유리한 무역환경을 조성할 필요가 있음. 인도의 경우 2007년말 까지 최빈국에 대한 관세를 철폐할 예정임

\section{- 중국}

- G77의 입장을 지지함.

- MDG를 포함한 국제 개발 목표를 달성하는 데에는 여러 가지 장애요인 존재

- 자본을 절실히 필요로 하는 빈국으로의 민 자 유입 부진

- 전년대비 2006년도 ODA 규모의 감소

- 개도국의 수출을 저해하는 새로운 무역규제 들의 등장

- 이러한 상황을 개선하려면 먼저 개도국들의 능력 배양을 지원해야 하며, ODA 규모를 확
대하고 개도국의 무역 경쟁력을 제고하는 방 안을 강구해야 함

- 또한 국제자본의 흐름을 적절히 통제함으로 써 금융위기를 예방하는 한편 국제금융기구 의 개혁을 통해 개도국의 입장을 반영할 수 있는 체제를 갖추어야 함

\section{- 브라질}

- G77의 입장을 지지함. 브라질은 개별 국가들 이 자신의 발전에 책임을 져야하며 국제개발 협력은 개별 국가의 노력을 지원하는 역할을 해야 한다는 몬테레이 컨센서스의 취지에 동 의함

- 브라질은 거시경제적 안정 및 성장을 소득 분 배와 조화시키는 데 성공하고 있으며, $\mathrm{MDG}$ 목표가 설정된 이후 4 천만명의 브라질 국민 이 절대빈곤에서 벗어났음

- 개도국의 개발을 촉진하기 위해서는 건전한 경제정책의 시행, 개발을 염두에 둔 무역체제 형성, 남-남 협력의 활성화 등이 필요

[자료: 주국제연합대표부] 